\title{
Global impact of COVID-19 pandemic on road traffic collisions
}

\author{
Yasin J. Yasin ${ }^{1,2}$, Michal Grivna ${ }^{1}$ and Fikri M. Abu-Zidan ${ }^{3^{*}}$ (1)
}

\begin{abstract}
Background: Various strategies to reduce the spread of COVID-19 including lockdown and stay-at-home order are expected to reduce road traffic characteristics and consequently road traffic collisions (RTCs). We aimed to review the effects of the COVID-19 pandemic on the incidence, patterns, and severity of the injury, management, and outcomes of RTCS and give recommendations on improving road safety during this pandemic.

Methods: We conducted a narrative review on the effects of COVID-19 pandemic on RTCs published in English language using PubMed, Scopus, and Google Scholar with no date restriction. Google search engine and websites were also used to retrieve relevant published literature, including discussion papers, reports, and media news. Papers were critically read and data were summarized and combined.

Results: Traffic volume dropped sharply during the COVID-19 pandemic which was associated with significant drop in RTCs globally and a reduction of road deaths in 32 out of 36 countries in April 2020 compared with April 2019, with a decrease of $50 \%$ or more in 12 countries, 25 to $49 \%$ in 14 countries, and by less than $25 \%$ in six countries. Similarly, there was a decrease in annual road death in 33 out of 42 countries in 2020 compared with 2019, with a reduction of $25 \%$ or more in 5 countries, $15-24 \%$ in 13 countries, and by less than $15 \%$ in 15 countries. In contrast, the opposite occurred in four and nine countries during the periods, respectively. There was also a drop in the number of admitted patients in trauma centers related to RTCs during both periods. This has been attributed to an increase in speeding, emptier traffic lanes, reduced law enforcement, not wearing seat belts, and alcohol and drug abuse.
\end{abstract}

Conclusions: The COVID-19 pandemic has generally reduced the overall absolute numbers of RTCs, and their deaths and injuries despite the relative increase of severity of injury and death. The most important factors that affected the RTCs are decreased mobility with empty lines, reduced crowding, and increased speeding. Our findings serve as a baseline for injury prevention in the current and future pandemics.

Keywords: COVID-19, Road traffic collision, Road safety, Injury, Death, Speed, Alcohol, Distraction

\section{Introduction}

The world is currently under the major impact of the COVID-19 pandemic. The disease spread swiftly and globally from Wuhan, China, the epicenter of the coronavirus, to the rest of the world, which was facilitated by fast transportation methods [1,2]. Struggle is continuing

*Correspondence: fabuzidan@uaeu.ac.ae

${ }^{3}$ Department of Surgery, College of Medicine and Health Sciences, UAE University, Al-Ain, United Arab Emirates

Full list of author information is available at the end of the article to contain the spread of the repeated waves of infection. The dynamics of infectious pandemics is different from other natural disasters [3-5]. Although they do not cause mass destruction to the infrastructure, they significantly and directly affect the community health and economy [6]. The lack of strong evidence about the transmission routes of the virus at the beginning of the epidemic [1] and inadequate preventive measures increased the rapid spread of the virus [1,3]. Overtime, better understanding of the infection routes with increased diagnostic tools, reporting, and tracing became more feasible [7-10]. 
Countries started implementing various national strategies to reduce the spread of the pandemic including physical distancing, quarantine, stay-at-home orders, closure of schools, restrictions of travel and mass gatherings, and complete lockdown $[7,8]$. These measures reduced road traffic movements and changed traffic characteristics [3, 7], which in turn affected road traffic collisions (RTCs) [11]. Congestion, speed, density, and flow of traffic are interlinked [12]. The increased number of empty lanes following travel restrictions reduced road congestion and increased traffic flow [13, 14].

RTCs is a global health problem. It causes around 1.35 million deaths per year worldwide [15] costing around $\$ 1.8$ trillion every year $[16,17]$. In contrast, COVID-19 pandemic caused around 4 million deaths [18], and a global gross domestic product reduction of around 10\% [19]. Understanding the impact of COVID-19 on RTCs is important and relevant to trauma surgeons and disaster medicine leaders. We aimed to review the effects of the COVID-19 pandemic on the incidence, patterns, and severity of the injury, management, and outcomes of RTCs and to give recommendations on improving road safety during this and future pandemics.

\section{Methods}

\section{The planning phase}

In the initial planning phase of this study, the authors discussed and aimed to review the different effects of the COVID-19 pandemic on RTCs. This was followed by structuring the general outline of different sections of the paper to be addressed. Based on this outline, we defined the search strategy, sources of literature, and inclusion and exclusion criteria for the literature search.

\section{Data source and search strategy}

We followed several procedures to ensure a high-quality review. First, we searched electronic databases, mainly PubMed, Scopus, and Google Scholar, using a wide range of search terms and keywords or a combination of keywords on the two central concepts: COVID-19 and RTC, to retrieve the published articles. The keywords include COVID-19, SARS-CoV-2, novel, coronavirus, pandemic, lockdown, quarantine, stay-at-home, shelter-in-place, safer-at-home, social restriction, social distancing, road, traffic collisions, traffic accidents, traffic crashes, motor vehicle, fatality, mortality, death, injury, travel behavior, mobility behavior, public transport, speed, drug, alcohol use, drinking, driving, psychological stress, anxiety, depression, trauma centers, emergency, orthopedic, trauma, emergency surgery, and trauma volume. Second, bibliographic references of these retrieved articles were used to obtain additional relevant papers. Third, the google search engine was used for collecting published discussion papers, reports, and media news. Finally, as a fourth step, several websites were searched to extract and collect published literature.

\section{Inclusion and exclusion criteria}

We included peer-reviewed journal articles, discussion papers, reports, and media news related to the effect of the COVID-19 pandemic on RTCs over the last 18 months, which is up to June 2021. No exclusions were made based on the article types, methodology of the study, outcome reported, study period, the scope of the study, and study setting. In other words, any literature related to the effect of the COVID-19 pandemic on RTCs was included. Literature was excluded if the language of publication was not English.

\section{Data extraction and synthesis}

Based on the primary outline of the study, the findings were critically summarized, data extracted, combined and synthesized using a narrative synthesis.

\section{Results and discussion \\ Effects on traffic congestion}

Reduction in traffic congestion affects speed, traffic flow, and traffic density $[12,20]$. Reduced mobility may decrease vehicle congestion, which in turn reduces road traffic collisions [21-26]. In contrast, it will increase empty road lanes, which may increase speeding (Fig. 1). During the COVID-19 pandemic, travel restrictions had significantly reduced vehicle mobility [27-32] which was reduced by more than $50 \%$ worldwide [28], with a decrease of 50 to $60 \%$ in the Asian countries [28] and 55 to $80 \%$ in the European countries [11, 22, 33, 34]. These resulted in a significant decline in public transport (60 to $80 \%$ ), private cars, driving, and walking globally during March-May 2020 [28-30, 35-37]. Furthermore, there was a significant reduction among public transport users in Latin America and the Caribbean (by 60 to 90\%) [28, 38 ] and European countries (by 40 to 90\%) [21, 22, 30, 33, 39]. Similarly, there was a reduction in car trips (or private car trips) by 65 to $80 \%$ in European countries [33, 40]. Overall, these resulted in a sharp decrease in traffic congestion [41, 42].

The reduction of traffic congestion has varied considerably in different countries [41, 43, 44]. It ranged between 25 and $75 \%$ during lockdown periods in different European countries, with the highest decrease of 75\% in France, Spain, and Italy in April 2020 compared with April 2019 [43] (Table 1). Similarly, traffic reduced by $40 \%$ in the USA [45], 63\% in the UK [46], 77\% in South Africa, $74 \%$ in New Zealand, 60\% in Israel, 59\% in Mexico, and $43 \%$ in Australia during the same period compared with April 2019 [43]. It is worth noting that the changes in 


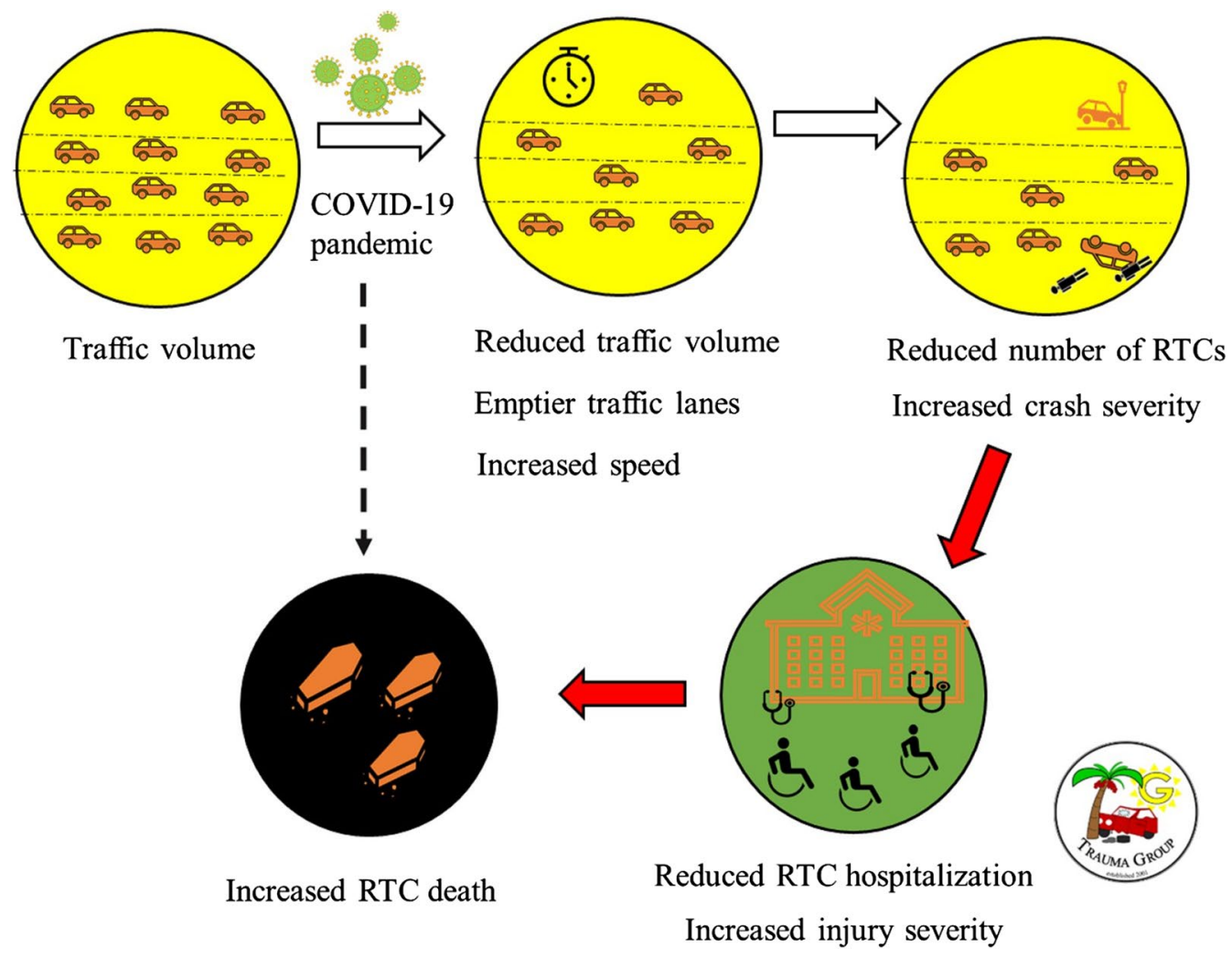

Fig. 1 Overall impact of the COVID-19 pandemic on traffic volume, traffic lanes, vehicle speed, number of road traffic collisions, injury severity, hospitalization, and RTC deaths

traffic reduction may fluctuate depending on the comparison periods $[43,44]$ (Table 1 ). Traffic reduction varied by the local setting, jurisdictions [23, 47-51], type and function of the road [43, 44], residence (urban and rural) [41, $44,52]$ and vehicle types $[43,44,46]$.

The drop in traffic congestion was not only related to the COVID-19 lockdown. Traffic declined in Sweden (by $22 \%$ ) and Netherland (by 35\%), although they were not under lockdown [43, 44]. Reduced transportation has negative effects on the economy $[19,43]$. Travel by private cars increased when restrictions were lifted [53]. In India, more than $90 \%$ of public transport users felt unsafe to be infected compared with $13 \%$ of those using private transportation [54]. Traffic congestion of major cities was reduced by around $15 \%$ worldwide. Nevertheless, it increased by $4 \%$ in few cities like Changchun in China [41]. Analyzing traffic congestion indicates that vehicle travel distance is one of the risk factors for RTCs [55].

\section{Effects on vehicle speed}

Excessive speed, which is anticipated to increase the incidence and severity of RTCs [12], has occurred during the COVID-19 pandemic [20, 56-61]. This was attributed to the significant reduction in traffic volumes and empty roads $[42,44,58,59,62,63]$ which encouraged high speeding [20,42, 47, 56, 57, 60, 64], and resulted in more RTCs despite the few numbers of vehicles [56, 60]. Furthermore, traffic speed enforcement was less [20,44]. Over-speeding increased by 39\% in Spain, 22\% in Estonia, 16\% in France, and 10\% in Denmark [44]. Extreme speeding offenses increased by $236 \%$ in the UK [63]. In the USA, over-speeding increased in various metropolitan cities by 13 to $64 \%$ during the COVID-19 restrictions [56].

High speed was a key factor for the rise in road fatalities in Northern Ireland and USA despite the quarantine [20, 48, 51, 62]. Road fatalities, attributed to over-speeding and unbelted passengers, increased by $78 \%$ in Virginia, USA, despite the reduced incidence of road collisions by $45 \%$ [65]. These results were inconsistent in all countries. Although serious speeding increased in France and Germany, road collisions in these countries decreased by $74 \%$ and $23 \%$, respectively [44]. In contrast, the speed-related vehicle collisions decreased in Minnesota (USA) and the Czech Republic despite reduced traffic volumes during lockdown $[23,44]$. In Nepal, $25 \%$ of the RTCs were attributed to speeding during the pandemic [57]. 
Table 1 Road traffic and road deaths during COVID-19 pandemic

\begin{tabular}{|c|c|c|c|c|c|}
\hline \multirow[t]{2}{*}{ Country } & \multirow{2}{*}{$\begin{array}{l}\text { Traffic volume (\% change) } \\
\text { April } 2020 \text { versus April } \\
2019\end{array}$} & \multicolumn{2}{|l|}{ Road deaths (\% change) } & \multirow{2}{*}{$\begin{array}{l}\text { Annual road } \\
\text { deaths (\% } \\
\text { change) } \\
2020 \text { versus } 2019\end{array}$} & \multirow[t]{2}{*}{ References } \\
\hline & & $\begin{array}{l}\text { April } 2020 \text { versus April } \\
2019\end{array}$ & $\begin{array}{l}\text { April } 2020 \text { versus April } \\
2017-2019 \text { average }\end{array}$ & & \\
\hline Albania & NA & NA & NA & -20 & [117] \\
\hline Australia & -43 & -23 to -24 & NA & -7 & {$[43,135,136]$} \\
\hline Austria & -50 & -25 to -30 & -9 & -19 & {$[24,43,44]$} \\
\hline Belgium & $\begin{array}{l}-60 * \text { March } 2020 \text { versus } \\
\text { March 2018-2019 }\end{array}$ & -68 & -68 & -22 & {$[24,44]$} \\
\hline Bosnia and Herzegovina & NA & NA & NA & -7 & [117] \\
\hline Bulgaria & NA & NA & NA & -26 & {$[24]$} \\
\hline Canada & NA & -34 & -46 & $+22 *$ Ontario & {$[43,101,137]$} \\
\hline Chile & - 56.5 (Santiago city) & - 24 (June on June) & NA & NA & {$[43]$} \\
\hline Columbia (*Cali) & $\begin{array}{l}-70 \text { *April } 2020 \text { versus } \\
2016-2019\end{array}$ & & $\begin{array}{l}-55 * \text { Compared to } \\
2016-2019\end{array}$ & NA & [138] \\
\hline Croatia & $\begin{array}{l}-50 * \text { April } 2020 \text { versus } \\
\text { April } 2018-2019\end{array}$ & -39 & -35 & -20 & {$[24,44]$} \\
\hline Cyprus & $\begin{array}{l}-65 \text { (urban areas) and }-70 \\
\text { (motorways) *April } 2020 \\
\text { versus February } 2020\end{array}$ & -100 & -100 & -8 & {$[24,44]$} \\
\hline \multirow[t]{2}{*}{ Czech Republic } & -50 (motorways) & -11 to -15 & +5 & -16 & {$[24,43,44]$} \\
\hline & $\begin{array}{l}\text { - } 65 \text { (urban areas) *April } \\
\text { versus February } 2020 \text { and } \\
\text { before }\end{array}$ & & & & \\
\hline Denmark & -25 & +9 & +6 & -22 & $[24,43,44]]$ \\
\hline Estonia & $\begin{array}{l}\text { - 10*April } 2020 \text { versus } \\
\text { April 2018-2019 }\end{array}$ & -25 & -18 & +15 & {$[24,44]$} \\
\hline Finland & -34 & -24 to -29 & -38 & +4 & {$[24,43,44]$} \\
\hline France & -75 & -56 & -61 & -21 & {$[24,43,44]$} \\
\hline Germany & -48 & -1 & -5 & -11 & {$[24,43,44]$} \\
\hline Greece & $\begin{array}{l}-42 \text { to }-74 * \text { March-April } \\
2020 \text { versus Feb } 2020\end{array}$ & -58 & -59 & -16 & {$[24,43,44,70]$} \\
\hline \multirow[t]{2}{*}{ Hungary } & -33 & -43 & -49 & -25 & {$[24,43,44]$} \\
\hline & $\begin{array}{l}\text { - } 41 * \text { April } 2020 \text { versus } \\
\text { April } 2017\end{array}$ & & & & \\
\hline Iceland & NA & NA & NA & +33 & {$[24]$} \\
\hline \multirow[t]{2}{*}{ Ireland } & -62 (Cars) & -22 & -36 & +6 & {$[24,43,44]$} \\
\hline & $\begin{array}{l}-65 \text { to }-70 \text { (National road } \\
\text { network) }\end{array}$ & & & & \\
\hline Israel & -60 & -28 & NA & NA & {$[43]$} \\
\hline Italy & -75 to -80 & -79 to -80 & -84 & -25 & {$[24,43,44]$} \\
\hline Japan & NA & NA & NA & -12 & [119] \\
\hline Kosovo & NA & NA & NA & -28 & {$[117]$} \\
\hline Latvia & NA & -33 & -25 & +7 & {$[24,44]$} \\
\hline Lithuania & -36 & -42 to -71 & -30 & -6 & {$[24,43,44]$} \\
\hline Luxembourg & NA & NA & +300 & +18 & {$[24,44]$} \\
\hline Macedonia (North) & NA & NA & NA & -5 & {$[117]$} \\
\hline Malta & NA & NA & NA & -31 & {$[24]$} \\
\hline Montenegro & NA & NA & NA & +2 & [117] \\
\hline Mexico & -59 & -23 & NA & NA & {$[43]$} \\
\hline Morocco & NA & -65 & NA & NA & {$[43]$} \\
\hline Nepal & $\begin{array}{l}-59 * \text { March } 24-J \text { une } 14 \\
2020 \text { versus } 2019\end{array}$ & NA & NA & NA & {$[57]$} \\
\hline
\end{tabular}


Table 1 (continued)

\begin{tabular}{|c|c|c|c|c|c|}
\hline \multirow[t]{2}{*}{ Country } & \multirow{2}{*}{$\begin{array}{l}\text { Traffic volume (\% change) } \\
\text { April } 2020 \text { versus April } \\
2019\end{array}$} & \multicolumn{2}{|l|}{ Road deaths (\% change) } & \multirow{2}{*}{$\begin{array}{l}\text { Annual road } \\
\text { deaths (\% } \\
\text { change) } \\
2020 \text { versus } 2019\end{array}$} & \multirow{2}{*}{ References } \\
\hline & & $\begin{array}{l}\text { April } 2020 \text { versus April } \\
2019\end{array}$ & $\begin{array}{l}\text { April } 2020 \text { versus April } \\
2017-2019 \text { average }\end{array}$ & & \\
\hline Netherlands & -35 & +6 & +13 & -8 & {$[24,43,44]$} \\
\hline New Zealand & -74 & -80 & NA & -9 & {$[43,139]$} \\
\hline Norway & -25 & -46 & -19 & -11 & {$[24,43,44]$} \\
\hline Poland & NA & -32 & NA & -15 & {$[24,43]$} \\
\hline Portugal & NA & -50 to -59 & -46 & -18 & {$[24,43,44]$} \\
\hline Romania & NA & -46 & -52 & -12 & {$[24,44]$} \\
\hline Saudi Arabia & $\begin{array}{l}-26 \text { to }-55^{*} \text { March-April } \\
2020 \text { versus February } 2020\end{array}$ & NA & NA & -20 & {$[70,118]$} \\
\hline Serbia & NA & -49 & NA & -8 & {$[43,117]$} \\
\hline Slovakia & NA & +50 & +20 & -9 & {$[24,44]$} \\
\hline Slovenia & -54 & -42 & -40 & -22 & {$[24,43,44]$} \\
\hline South Africa & -77 & -78 & NA & NA & {$[43]$} \\
\hline South Korea & NA & NA & NA & $-12 *$ Seoul & {$[140]$} \\
\hline Spain & $\begin{array}{l}-75(-75 * \text { April } 2020 \\
\text { versus April 2017-2019) }\end{array}$ & -49 to -59 & -63 & -21 & {$[24,43,44]$} \\
\hline Sweden & $\begin{array}{l}-22(-22 * A p r i l \\
-2020 \\
\text { versus Apr 2017-2019) }\end{array}$ & +6 & +2 & -14 & {$[24,43,44]$} \\
\hline Switzerland & NA & NA & NA & +21 & {$[24,124]$} \\
\hline Uruguay & NA & -51 & NA & NA & [43] \\
\hline UK & -63 & -48 & NA & -14 & {$[46,109]$} \\
\hline USA & -40 & -18 & NA & +7 & {$[45,110]$} \\
\hline
\end{tabular}

NA not available

\section{Effects on traffic lanes}

The number of empty/open traffic lanes increased during the COVID-19 pandemic, which was attributed to the reduced traffic volumes following travel restrictions $[44,62,66,67]$. The impact of these empty/open traffic lanes on excessive speed and associated accidents has been less studied. A report by the National Safety Council, USA, showed that the increased number of empty traffic lanes contributed to excessive speed and increased road death rates in several states during the quarantine [62]. Another study found that empty lanes were associated with increased speed and collisions [14].

Furthermore, several major cities across the globe, such as Philadelphia, Calgary, Berlin, Bogota temporarily replaced traffic lanes with sidewalks and bike lanes to support walking and bicycling by providing more space for pedestrians and cyclists $[44,66]$. This was an attempt to improve physical activity and mitigate the psychological effects of the COVID-19 pandemic [6]. Empty lanes encouraged cycling in different major cities of Europe [67]. On the contrary, these empty lanes encouraged extreme speed that resulted in fatality crashes in several other cities [63].

\section{Effects on driving behaviors}

Understanding the driving behavior of traffic users is essential for improving road safety during the pandemic [68, 69]. A study from Greece and Saudi Arabia found that the reduced traffic volume during the lockdown increased speed, harsh acceleration, repeated harsh braking, and the usage of mobile cellphones [70]. Adolescent driving time and distance decreased by around $35 \%$, during movement restriction. These changes were less in older, employed, and ethnic minority adolescents but greater in those with greater social tendencies [71]. Interestingly, there was generally a reduction in distraction-related RTCs in Louisiana, USA by $43 \%$ during the lockdown, although there was a slight increase in injuries among drivers using mobile phones [72]. Similarly, fatalities with unrestrained drivers increased by $15 \%$ in Virginia [65] and 11\% in Minnesota, USA [73] indicating a decrease in seat belt compliance [20,74]. During the COVID-19 pandemic drivers in US and Canada were more likely to drive distracted, not wearing seat belts, over-speeding, and using drugs $[75,76]$. 


\section{Effects on drug and alcohol abuse}

The impact of the COVID-19 pandemic on drug and alcohol-induced traffic collisions has been less studied compared with the impact of the pandemic on health behavior changes. Travel and social restrictions, psychological stress, anxiety, and fear of exposure to the virus were associated with increased alcohol consumption during the pandemic [77-80]. Alcohol consumption was increased by $14 \%$ in Washington, USA [77]. Increased alcohol and drug consumption were attributed to more free time during the COVID-19 pandemic $[61,78]$. This may lead to over-speeding, impaired driving, and stunt driving, with reduced road safety [20, 61, $72,81]$. Increased drug and alcohol consumption may lead to increased suicide, domestic violence [82], and risky driving $[20,72,75,81-83]$. Thomas et al. found a significantly higher overall prevalence of drug and alcohol use in seriously and fatally injured RTCs patients, being $65 \%$ during the pandemic compared with $51 \%$ before that [81]. This included an increase in alcohol use, cannabinoids, and opioids (28\% compared with $22 \%$, 33\% compared with $21 \%$, and $14 \%$ compared with $8 \%$, respectively) [81]. However, other studies from Canada and USA showed a slight reduction (around $3 \%)$ in alcohol use during the pandemic $[75,83]$.

\section{Effects of psychological impact on RTCs}

The COVID-19 pandemic has a major psychological impact on the community affecting the mental health and vulnerable groups. This is exaggerated by the preventive measures taken to fight the virus, including quarantine, lockdown, self-isolation, and social distancing, which are unusual human behaviors [6, 84, 85]. Negative emotions, such as depression and anxiety, increased after the COVID-19 outbreak [86-88]. Fear of dying, death of family members, fear of stigma, reduced social interaction, and lockdown are potential risk factors of mental health problems [6]. Furthermore, the global failure to find an effective treatment or vaccine for the pandemic, or their shortages is another factor causing psychological pressure, not only to the infected persons but also to the healthy individuals [89]. Negative emotions such as depression, sadness, anxiety, stress, fatigue, distraction have a deleterious effect on driving behaviors and speeding [90-92]. The effects of these negative emotions on driver performance and speeding during the COVID-19 pandemic and its impact on RTCs have not been adequately examined [93]. COVID1-19 pandemic may negatively affect drivers' mood, which is associated with anxiety and aggressive driving leading to tragic outcomes [94].

\section{Incidence of RTCs}

RTCs are related to the risk of exposure to traffic, human behavior, vehicle design, traffic volumes, road infrastructure, and environmental conditions [12, 23, 95, 96]. Although travel restrictions have different effects on the above factors, the effects on road infrastructure, environment, and vehicle design are unchanged. Traffic volume and open/empty traffic lanes possibly affect human behavior [12, 13, 26, 97]. Road traffic collisions during the COVID-19 restrictions were generally reduced globally $[11,21,44,51,56,98-100]$ which is attributed to the reduced traffic volumes [21, 23, 40, 44, 47]. This reduction varies considerably by country and the type and function of roadways [56]. It was $67 \%$ in Spain [11], 26\% in Canada [101], 84\% in UAE [102], 48\% in Nepal [57], $30-60 \%$ in Turkey $[99,103], 11$ to $58 \%$ in USA $[23,56,59$, 72, 104], 29 to 53\% in Northern Ireland [51, 105], 74\% in France, 28\% in Czech Republic, and 23\% in Germany [44] during lockdowns.

\section{Severity of RTCs}

It is important to clarify that although the numbers of RTCs may have reduced and the absolute number of RTC death may decrease, the relative percentage of victims having severe injuries or death may increase despite the overall reduced standardized RTC population death rate $[42,56,59,98]$, (Fig. 1). For example, the decline of RTCs in Missouri, USA, during the mandated lockdown resulted in decreased mild injuries, but not in serious/ fatal injuries [98].

This can be attributed to the increased speed [14, 59, 106], empty lanes, and reduced law enforcement during COVID-19 lockdown [20, 42, 44, 62]. Severe injuries will increase the morbidity, mortality of injured patients, and medical treatment costs [59, 107]. Speeding was the main factor for fatal collisions during the COVID-19 lockdown $[42,56,59]$. The ratio of deadly crashes to all crashes dramatically increased due to excessive speed by $470 \%$ in Madrid (Spain), by 292\%, in Chicago, by $167 \%$ in New York, and by $65 \%$ in Boston [63]. The fatality rate increased by $14 \%$ per miles driven across the US states during March 2020 [62] and by 37\% per miles driven during April 2020 [63], which was attributed to extreme speed $[42,56]$. This was reflected in studies from trauma centers that demonstrated an increase of injury severity of an ISS above nine of admitted patients from $35 \%$ before the lockdown to about $63 \%$ during the lockdown [108].

As explained above, the absolute number of fatal accidents, severe injuries, and mild injuries of RTCs declined by $41 \%, 8 \%$, and $42 \%$, in Greece, respectively [70]. Similarly, in Australia, the absolute number of fatal crashes 
decreased by $10 \%$ in 2020 compared with the prior threeyear, which varied depending on jurisdictions, except in Queensland, where it increased by 11\% [49]. Likewise, there was a reduction in the number of fatal collisions by $35 \%$ in New York City and 56\% across mainland France in April 2020 compared with April 2019 [63].

\section{Outcome of RTCs}

The significant reduction of RTCs during the COVID-19 lockdown had different clinical outcomes [43, 44]. There was a significant decrease in the number of traffic-related deaths and injuries in most of the countries. Nevertheless, the opposite occurred in others. This is because the decline in traffic may increase risky driving behaviors such as over-speeding with increased severity of injury despite the decrease in the incidence of RTCs [43, 56, $59,75,81]$. The strict lockdown during the pandemic reduced the number of RTCs deaths globally $[43,44,57$, 99, 109-111] (Table 1).

In contrast, the absolute number of road deaths in April 2020 increased in Slovakia (50\%) and Denmark (9\%) compared with April 2019 [43, 44]. Similarly, there was an increase in the number of road fatalities in The Netherland (6\%) and Sweden (6\%) in April 2020 compared with April 2019, although there were no lockdown measures in these countries [43, 44].

Death is mainly caused by high-energy transfer from the vehicle to the road traffic users during the crash. The mortality of pedestrians and motorcyclists are much higher compared with vehicle occupants in the same setting because the pedestrians and motorcyclists are vulnerable road users (pedestrians, cyclists, and motorcyclists) compared with the vehicle occupants $[112,113]$. The interaction between the road infrastructure, environment, size and speed of a vehicle, behavior of drivers, traffic mobility, congestion, empty lines will explain the differences in mortality between different states and countries [114-116]. The reduction of road deaths on rural roads in Spain during lockdown by $62 \%$ resulted in a $10 \%$ reduction of the number of road deaths among vulnerable road users (from 37\% before lockdown to 27\% during lockdown) [44]. Similarly, the reduction of death or seriously injured pedestrians (by 24\%) and motorcyclists (by 16\%) were less compared with passengers (by 38\%) in Northern Ireland, UK [51]. In Australia, there was reduction of the number road traffic deaths among pedestrians (by $20 \%$ ), motorcyclists (by $12 \%$ ), passengers (by $11 \%$ ), and drivers (by $5 \%$ ), but cyclists death increased by $29 \%$ during the initial stage of the lockdown compared with the prior three years [49]. In contrast, road fatality among vulnerable road users increased in the Czech Republic during the lockdown (by 27\%); cyclists and motorcyclists death increased by $86 \%$ and $50 \%$, respectively [44].

Notably, the effect of the COVID-19 pandemic on road deaths continued after the lockdown periods. Overall, the number of annual road death dropped significantly in most countries. However, few had the opposite. There was an overall reduction in the annual absolute number of road deaths in most of the 27 European countries by $17 \%$ [24], six Balkan countries by 11\% [117], in Saudi Arabia by $20 \%$ [118], and in Japan by $12 \%$ [119, 120]. In contrast, the absolute number of road deaths increased in some countries like Luxembourg by $18 \%$, Ireland by $6 \%$, Finland by $4 \%$, and Switzerland by $21 \%$ [24, 117]. Similarly, it generally increased in the USA by 7\% [110] with major variations in different states [121].

\section{Hospitalization in trauma centers}

The reduction of RTCs during the COVID-19 pandemic reduced the number of treated trauma patients at trauma centers globally by 20 to $85 \%$ compared with previous years $[25,60,107,108,122-127]$. This was shown in different countries worldwide like China [126], Spain [125], India [127], South Africa [25], UK [60, 105, 108], USA [107, 128-130], Australia [124], Ireland [131], and New Zealand [132]. A study conducted by Ajayi et al. (2020) in UK found a decrease in trauma admissions during COVID-19 lockdown despite an increased incidence of road collisions [133] (Table 2).

\section{Cost}

A significant amount of money was saved from avoiding collisions during the COVID-19 pandemic. These savings are related to material damage, human cost (life and pain), treatment of injuries, lost time at work, and administrative costs, including insurance claims and emergency response [12, 47]. California State, USA, saved more than one billion USD due to reductions in vehicle collisions after the lockdown order [47]. The savings ranged from 7 to 24 billion USD in other five US states [104]. Despite that, the costs of RTCs are still expensive despite the quarantine [134]. Overall, the cost of motor vehicle deaths, injuries, and property damage in the USA was estimated to be more than 474 billion USD in 2020 [121].

\section{Recommendations}

- Ensuring road safety legislations, including its enforcement, driving license requirements, and alcohol consumption regulations during the COVID-19 pandemic.

- Collaborative efforts among different stakeholders, including research institutions, police, hospitals, transport and safety departments, insurance compa- 


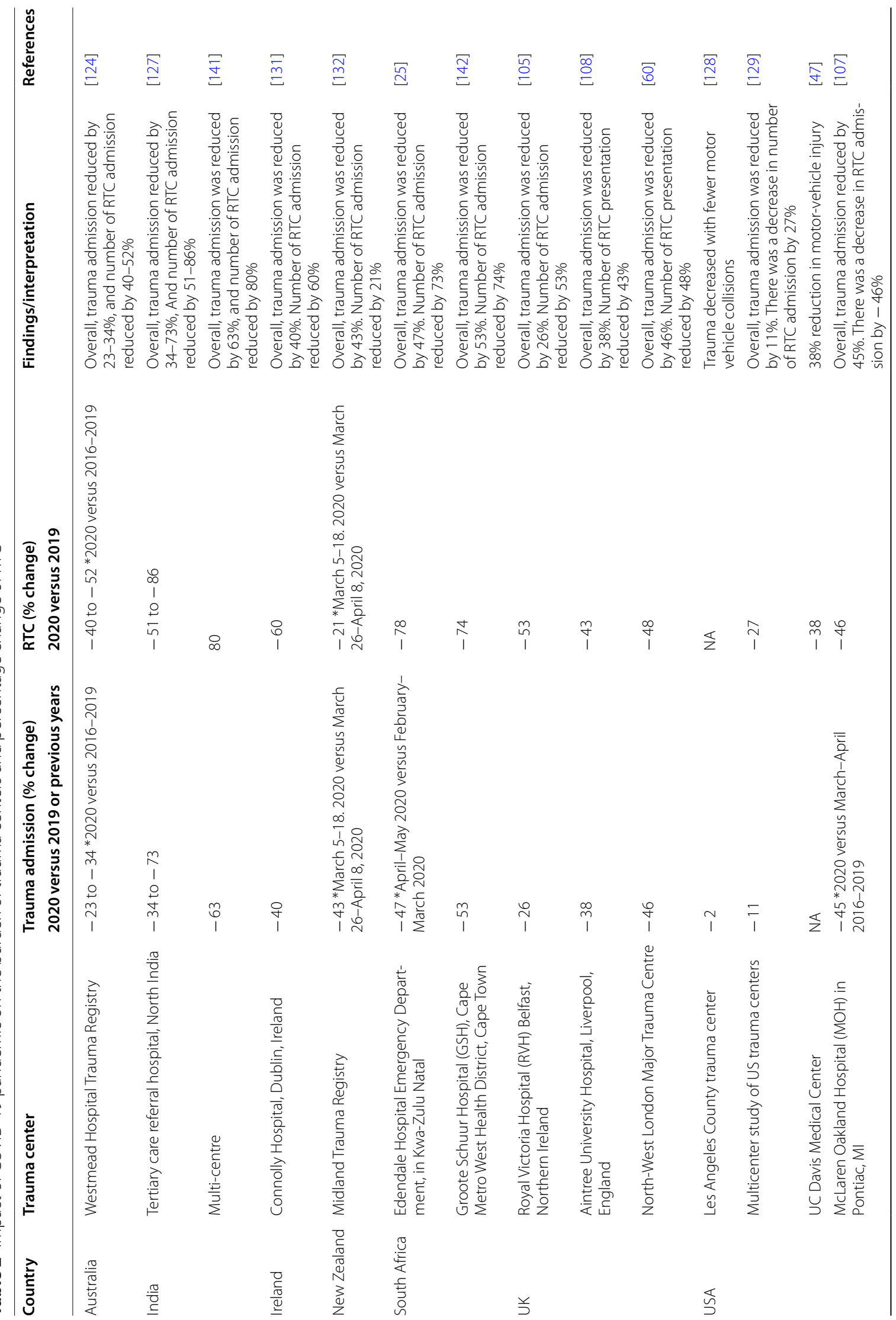




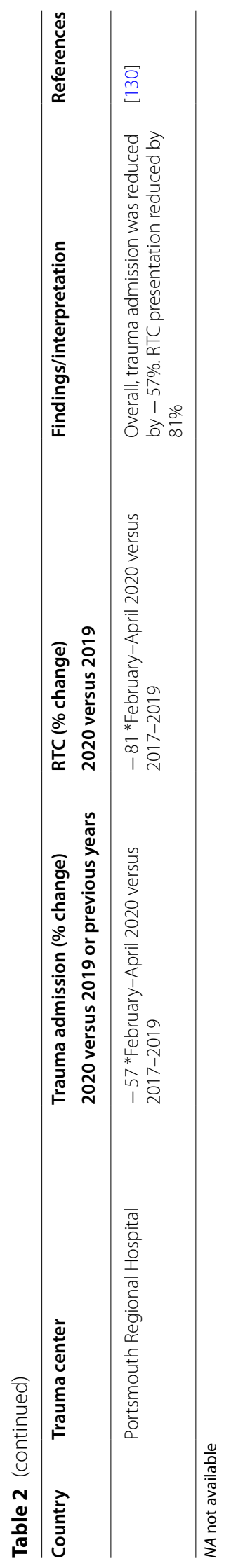


nies on national and international levels to coordinate and act on the needed response to increase road safety during infectious pandemics.

- Review the lessons learned on RTCs during the COVID-19 pandemic and use them to mitigate the effects of the current and future pandemics.

- Have a comprehensive digitalized data record to study the impact of the COVID-19 pandemic on road safety and use the generated data to monitor and plan future disaster management of pandemics.

- Carry out comprehensive studies on road safety during the COVID-19 pandemic with appropriate methodological approach and research funds. This should include studies from rural areas and developing countries.

\section{Conclusions}

The COVID-19 pandemic has generally reduced the overall absolute numbers of RTCs, and their deaths and injuries despite the relative increase of severity of injury and death. The most important factors that affected the RTCs are decreased mobility with empty lines, reduced crowding, and increased speeding. Our findings serve as a baseline for injury prevention in the current and future pandemics. Future research with a comprehensive methodological approach that includes rural areas and developing countries is demanded.

\section{Abbreviations \\ RTC: Road traffic collisions; UAE: United Arab Emirates; UK: United Kingdom; USA: United States of America; USD: United States Dollar.}

\section{Acknowledgements}

Not applicable.

\section{Authors' contributions}

Conceived and planned the review: YJY, MG, FAZ. Retrieved and ctitically summurized the literature: YJY. drafted the paper:YJY, FAZ. Critically read and edited the paper FAZ. Read and approved the final version: YJY, MG, FAZ. All authors read and approved the final manuscript.

\section{Funding}

None.

Availability of data and materials

Not applicable.

\section{Declarations}

Ethics approval and consent to participate

Data used are public published data which is an exempt of the approval the human research ethics committee.

\section{Consent for publication}

Not applicable.

\section{Competing interests}

The authors declare that they have no competing interests.

\section{Author details}

${ }^{1}$ Institute of Public Health, College of Medicine and Health Sciences, UAE University, Al-Ain, United Arab Emirates. ${ }^{2}$ Department of Environmental Health and Behavioral Sciences, School of Public Health, College of Health Sciences, Mekelle University, Mekelle, Ethiopia. ${ }^{3}$ Department of Surgery, College of Medicine and Health Sciences, UAE University, Al-Ain, United Arab Emirates.

Received: 15 July 2021 Accepted: 17 September 2021

Published online: 28 September 2021

\section{References}

1. World Health Organization. Novel Coronavirus (2019-nCoV) Situation Report-1.WHO Bulletin. 2020. Available at https://www.who.int/docs/ default-source/coronaviruse/situation-reports/20200121-sitrep-1-2019ncov.pdf?sfvrsn=20a99c10_4. Accessed 25 Mar 2021.

2. Rodrigue J, Luke T, Osterholm M. Transportation and pandemics. 2009;1-5. Available at https://transportgeography.org/?page_id=8869. Accessed 25 Mar 2021.

3. Parr S, Wolshon B, Renne J, Murray-Tuite P, Kim K. Traffic impacts of the COVID-19 pandemic: statewide analysis of social separation and activity restriction. Nat Hazards Rev. 2020;21:04020025.

4. Kim K, Francis O, Yamashita E. Learning to build resilience into transportation systems. Transp Res Rec. 2018;2672:30-42.

5. Emergency Care Research Institute. Healthcare hazard control emergency preparedness and disasters 4: natural disasters. Vol. 3. 2006. p. 1-13. Available at https://www.ecri.org/Resources/Hurricane/Natural_ Disasters(Healthcare-Hazard-Control).pdf. Accessed 25 Mar 2021.

6. Sheek-Hussein M, Abu-Zidan FM, Stip E. Disaster management of the psychological impact of the COVID-19 pandemic. Int J Emerg Med. 2021;14:1-10.

7. World Health Organization. COVID-19 Strategy Update. 2020. Available at https://www.who.int/docs/default-source/coronaviruse/covid-strat egy-update-14april2020.pdf?sfvrsn=29da3ba0_19. Accessed $25 \mathrm{Mar}$ 2021.

8. World Health Organization. Report of the WHO-China Joint Mission on Coronavirus Disease 2019 (COVID-19). 2020. Available at https://www. who.int/docs/default-source/coronaviruse/who-china-joint-missionon-covid-19-final-report.pdf. Accessed 26 Mar 2021.

9. Riou J, Althaus CL. Pattern of early human-to-human transmission of Wuhan 2019 novel coronavirus (2019-nCoV), December 2019 to January 2020. Eurosurveillance. 2020;25:1-5.

10. Imai N, Shang Y, Inthavong K, Tu J, Dorigatti I, Cori A, et al. Report 2: estimating the potential total number of novel Coronavirus cases in Wuhan City, China. Ann Biomed Eng. 2020;48:1-4.

11. Saladié Ò, Bustamante E, Gutiérrez A. COVID-19 lockdown and reduction of traffic accidents in Tarragona Province, Spain. Transp Res Interdiscip Perspect. 2020;8:100218.

12. Wang C, Quddus MA, Ison SG. The effect of traffic and road characteristics on road safety: a review and future research direction. Saf Sci. 2013;57:264-75.

13. Martin JL. Relationship between crash rate and hourly traffic flow on interurban motorways. Accid Anal Prev. 2002;34:619-29.

14. Wang C, Quddus M, Ison S. A spatio-temporal analysis of the impact of congestion on traffic safety on major roads in the UK. Transp A Transp Sci. 2013;9:124-48.

15. World Health Organization. The Global status report on road safety. Vol. 2, Geneva. 2018. Available at https://www.who.int/violence_injury_ prevention/road_safety_status/2018/en/. Accessed 26 Mar 2021.

16. Hazen A, Ehiri JE. Road traffic injuries: hidden epidemic in less developed countries. J Natl Med Assoc. 2006;98:73-82.

17. Chen S, Kuhn M, Prettner K, Bloom DE. The global macroeconomic burden of road injuries: estimates and projections for 166 countries. Lancet Planet Health. 2019;3:e390-8.

18. World Health Organization. Weekly Operational Update on COVID-19. World Health Organisation. 2021;1-12. Available at https://www.who. int/publications/m/item/weekly-operational-update-on-covid-19---5july-2021. Accessed 07 July 2021.

19. Organization for Economic Co-operation and Development. Global economy faces a tightrope walk to recovery. 2021. Available at https:// 
www.oecd.org/newsroom/global-economy-faces-a-tightrope-walk-torecovery.htm. Accessed 24 Apr 2021.

20. Wagner E, Atkins R, Berning A, Robbins A, Watson C, Anderle J. Examination of the traffic safety environment during the second quarter of 2020: Special Report (Report No. DOT HS 813 011). 2020. Available at https://rosap.ntl.bts.gov/view/dot/50940. Accessed 15 May 2021.

21. Aloi A, Alonso B, Benavente J, Cordera R, Echániz E, González F, et al. Effects of the COVID-19 lockdown on urban mobility: empirical evidence from the city of Santander (Spain). Sustainability. 2020;12:3870.

22. Bucsky P. Modal share changes due to COVID-19: the case of Budapest. Transp Res Interdiscip Perspect. 2020;8:100141.

23. Devoe E, Leuer D, Saari I, Wagner M. Traffic safety impact of COVID-19: impact to Minnesota motor vehicle crashes, March 1 to May 18. 2020. Available at http://www.dot.state.mn.us/trafficeng/safety/docs/trafficsafety-impact-of-covid19.pdf. Accessed 17 Mar 2021.

24. European Commission. Mobility and Transport. European Commission. 2021. Available at https://ec.europa.eu/transport/modes/road/news/ 2021-04-20-road-safety_en. Accessed 23 May 2021.

25. Morris D, Rogers M, Kissmer N, Du Preez A, Dufourq N. Impact of lockdown measures implemented during the Covid-19 pandemic on the burden of trauma presentations to a regional emergency department in Kwa-Zulu Natal, South Africa. Afr J Emerg Med. 2020;10:193-6.

26. Cadar RD, Boitor MR, Dumitrescu M. Effects of traffic volumes on accidents: the case of Romania's national roads. Geogr Tech. 2017;12:20-9.

27. Barbieri DM, Lou B, Passavanti M, Hui C, Hoff I, Lessa DA, et al. Impact of COVID-19 pandemic on mobility in ten countries and associated perceived risk for all transport modes. PLoS ONE. 2021:16:1-18.

28. Medimorec N, Enriquez A, Hosek E, Peet K. Impacts of COVID-19 on mobility on urban mobility: preliminary analysis of regional trends on urban mobility. 2020. Available at https://slocat.net/wp-content/uploa ds/2020/05/SLOCAT_2020_COVID-19-Mobility-Analysis.pdf. Accessed 23 May 2021.

29. Lozzi G, Rodrigues M, Marcucci E, Teoh T, Gatta V, Pacelli V. Research for TRAN Committee-COVID-19 and urban mobility: impacts and perspectives. 2020;24. Available at https://www.europarl.europa.eu/ RegData/etudes/IDAN/2020/652213/IPOL_IDA(2020)652213_EN.pdf. Accessed 23 May 2021.

30. Gragera A, Albalate D, Schaj G, Aquilué I, Helder J, Espindola L, et al. Urban mobility strategies during COVID-19. 2021. Available at https:// www.eiturbanmobility.eu/wp-content/uploads/2021/03/Urban-mobil ity-strategies-during-COVID-19_long-1.pdf. Accessed 15 Apr 2021.

31. Vannoni M, McKee M, Semenza JC, Bonell C, Stuckler D. Using volunteered geographic information to assess mobility in the early phases of the COVID-19 pandemic: a cross-city time series analysis of 41 cities in 22 countries from March 2nd to 26th 2020. Global Health. 2020;16:1-9.

32. Nouvellet P, Bhatia S, Cori A, Ainslie KEC, Baguelin M, Bhatt S, et al. Reduction in mobility and COVID-19 transmission. Nat Commun. 2021;12:1-9.

33. de Haas M, Faber R, Hamersma M. How COVID-19 and the Dutch 'intelligent lockdown' change activities, work and travel behaviour: evidence from longitudinal data in the Netherlands. Transp Res Interdiscip Perspect. 2020;6:100150.

34. Hadjidemetriou GM, Sasidharan M, Kouyialis G, Parlikad AK. The impact of government measures and human mobility trend on COVID-19 related deaths in the UK. Transp Res Interdiscip Perspect. 2020;6:100167.

35. Lapatinas A. The effect of COVID-19 confinement policies on community mobility trends in the EU. 2020. Available at https://op.europa.eu/ en/publication-detail/-/publication/8642822d-b1 10-11ea-bb7a-01aa7 5ed71a1/language-en. Accessed 20 Apr 2021.

36. Liu L, Miller HJ, Scheff J. The impacts of COVID-19 pandemic on public transit demand in the United States. PLoS ONE. 2020;15:1-22.

37. Beck MJ, Hensher DA. Insights into the impact of COVID-19 on household travel and activities in Australia- the early days under restrictions. Transp Policy. 2020;96:76-93.

38. UN-Habitat. Cities and pandemics: towards a more just, green and healthy future. 2021. Available at https://unhabitat.org/sites/default/ files/2021/03/cities_and_pandemics-towards_a_more_just_green_ and_healthy_future_un-habitat_2021.pdf. Accessed 06 June 2021.

39. Jenelius E, Cebecauer M. Impacts of COVID-19 on public transport ridership in Sweden: analysis of ticket validations, sales and passenger counts. Transp Res Interdiscip Perspect. 2020;8:100242.
40. Aletta F, Brinchi S, Carrese S, Gemma A, Guattari C, Mannini L, et al. Analysing urban traffic volumes and mapping noise emissions in Rome (Italy) in the context of containment measures for the COVID-19 disease. Noise Mapp. 2020;7:114-22.

41. Tomtom. Traffic Index results 2020. 2020. Available at https://www. tomtom.com/en_gb/traffic-index/ranking/. Accessed 15 Apr 2021.

42. Meyer MW. COVID lockdowns, social distancing, and fatal car crashes: more deaths on Hobbesian Highways? Camb J Evid Based Policy. 2020:4:238-59.

43. International Transport Forum. Road safety report annual 2020. 2020. Available at https://www.itf-oecd.org/sites/default/files/docs/irtadroad-safety-annual-report-2020_0.pdf. Accessed 24 Apr 2021.

44. European Transport Safety Council. Pin briefing: the impact of Covid-19 lockdowns on road deaths in April 2020. 2020. Available at https://etsc. eu/wp-content/uploads/PIN-Corona-Briefing_final.pdf. Accessed 15 Feb 2021.

45. Federal Highway Administration. Traffic volume trends. Vol. 6. 2020. Available at https://www.fhwa.dot.gov/policyinformation/travel_monit oring/20aprtvt/20aprtvt.pdf. Accessed 05 May 2021.

46. Department for Transport. Road Traffic Estimates: Great Britain 2020. 2021. Available at https://assets.publishing.service.gov.uk/government/ uploads/system/uploads/attachment_data/file/981967/road-trafficestimates-in-great-britain-2020.pdf. Accessed 05 June 2021.

47. Shilling F, Waetjen D. Impact of COVID19 mitigation on numbers and costs of California traffic crashes impact of COVID19 mitigation on California traffic crashes. Vol. 2020. 2020. Available at https://roadecology. ucdavis.edu/files/content/projects/COVID_CHIPs_Impacts_updated_ 415_0.pdf. Accessed 10 Mar 2021.

48. Liu Z, Stern R. Quantifying the traffic impacts of the COVID-19 shutdown. J Transp Eng Part A Syst. 2021;147:04021014.

49. Catchpole J, Naznin F. Impact of COVID-19 on road crashes in Australia. 2020. Available at https://f.hubspotusercontent20.net/hubfs/3003125/ ADVICovid19ReportFINAL.pdf. Accessed 18 Apr 2021.

50. Carrington D. UK road travel falls to 1955 levels as Covid-19 lockdown takes hold. The Guardian. 2020. Available at https://www.theguardian. com/uk-news/2020/apr/03/uk-road-travel-falls-to-1955-levels-as-covid19-lockdown-takes-hold-coronavirus-traffic. Accessed 17 Mar 2021.

51. Police Service of Northern Ireland. Police recorded injury road traffic collisions and casualties Northern Ireland detailed trends report. 2020. Available at https://www.psni.police.uk/globalassets/inside-the-psni/ our-statistics/road-traffic-collision-statistics/2020/may/police-recordedinjury-road-traffic-collisions-and-casualties-may-2020.pdf. Accessed 20 Mar 2021.

52. Salas EB. COVID-19: Road traffic change in Brazil 2020. STATISTA. 2020. Available from https://www.statista.com/statistics/1108315/coron avirus-impact-vehicle-traffic-brazil-cities/. Accessed 21 Mar 2021.

53. Beck MJ, Hensher DA. Insights into the impact of COVID-19 on household travel and activities in Australia-the early days of easing restrictions. Transp Policy. 2020;99:95-119.

54. Pawar DS, Yadav AK, Akolekar N, Velaga NR. Impact of physical distancing due to novel coronavirus (SARS-CoV-2) on daily travel for work during transition to lockdown. Transp Res Interdiscip Perspect. 2020;7:100203.

55. Litman T. A new traffic safety paradigm. 2021. Available at www.vtpi. org/ntsp.pdf. Accessed 25 May 2021

56. Pishue B. COVID-19 Effect on collisions on interstates and highways in the US. 2020. Available at https://inrix.com/campaigns/the-riskiestroads-in-the-usa-report/. Accessed 05 Apr 2021.

57. Sedain B, Pant PR. Road traffic injuries in Nepal during COVID-19 lockdown. F1000Research. 2021;9:1-22.

58. Vandoros S, Papailias F. Empty streets, speeding and motor vehicle collisions during Covid-19 lockdowns: evidence from Northern Ireland. medRxiv. 2021. https://doi.org/10.1101/2021.01.03.21249173.

59. Hughes JE, Kaffine D, Kaffine L. Decline in traffic congestion increased accident severity in the wake of COVID-19. 2020;1-32. Available at https://spot.colorado.edu/ jonathug/Jonathan_E._Hughes/Main_files/ COVID_Accidents.pdf. Accessed 27 Apr 2021.

60. Park C, Sugand K, Nathwani D, Bhattacharya R, Sarraf KM. Impact of the COVID-19 pandemic on orthopedic trauma workload in a London level 1 trauma center: the "golden month." Acta Orthop. 2020;91:556-61. 
61. Vingilis E, Beirness D, Boase P, Byrne P, Johnson J, Jonah B, et al. Coronavirus disease 2019: what could be the effects on Road safety? Accid Anal Prev. 2020;144:105687.

62. National Safety Council. Motor vehicle fatality rates jump $14 \%$ in march despite quarantines. 2020. Available at https://www.nsc.org/in-thenewsroom/motor-vehicle-fatality-rates-jump-14-in-march-despitequarantines. Accessed 19 Apr 2021.

63. Masri L. Car crashes became deadlier during lockdowns across globe: Reuters Insight. Reuters. 2020. Available at https://www.reuters.com/ article/us-health-coronavirus-traffic-casualties/car-crashes-deadlier-asdrivers-speed-during-lockdowns-idUSKBN23X1OR. Accessed 21 Mar 2021.

64. Inada H, Ashraf L, Campbell S. COVID-19 lockdown and fatal motor vehicle collisions due to speed-related traffic violations in Japan: a time-series study. Injury Prev. 2021;27:98-100.

65. Virginia Department of Transportation. VDOT News - Statewide. 2020 Available at https://www.virginiadot.org/newsroom/statewide/2020/ volume-down-on-virginia-roadways\%C2\%A0while-unbelted-andspeed-related-crashes-and-fatalities-increase\%C2\%A06-19-2020.asp. Accessed 27 May 2021.

66. Laker L. World cities turn their streets over to walkers and cyclists. The Guardian. 2020;7-11. Available at https://www.theguardian.com/world/ 2020/apr/11/world-cities-turn-their-streets-over-to-walkers-and-cycli sts. Accessed 18 Mar 2021

67. Vandy K. Coronavirus: How pandemic sparked European cycling revolution. BBC News. 2020. Available at https://www.bbc.com/news/worldeurope-54353914. Accessed 15 Mar 2021.

68. Klauer SG, Guo F, Simons-Morton BG, Ouimet MC, Lee SE, Dingus TA. Distracted driving and risk of road crashes among novice and experienced drivers. N Engl J Med. 2014;370:54-9.

69. Faroog D, Moslem S, Tufail RF, Ghorbanzadeh O, Duleba S, Maqsoom A, et al. Analyzing the importance of driver behavior criteria related to road safety for different driving cultures. Int J Environ Res Public Health. 2020;17:1893

70. Katrakazas C, Michelaraki E, Sekadakis M, Yannis G. A descriptive analysis of the effect of the COVID-19 pandemic on driving behavior and road safety. Transp Res Interdiscip Perspect. 2020;7:100186.

71. Stavrinos D, McManus B, Mrug S, He H, Gresham B, Albright MG, et al. Adolescent driving behavior before and during restrictions related to COVID-19. Accid Anal Prev. 2020;144:105686.

72. Barnes SR, Beland L-P, Huh J, Kim D. The effect of COVID-19 lockdown on mobility and traffic accidents: evidence from Louisiana. GLO Discuss Pap. 2020;616. Available at http://hdl.handle.net/10419/222470. Accessed 19 May 2021.

73. Minnesota Department of Publuc Safety/Office of Traffic Safety. Minnesota Annual Report 2020. 2021. Available at https://dps.mn.gov/ divisions/ots/reports-statistics/Documents/Annual-Report-2020.pdf. Accessed 15 May 2021.

74. Office of Behavioral Safety Research. Traffic safety facts update to special reports on traffic safety during the COVID-19 public health emergency: third quarter Data. Vol. 2020. 2021. Available at https://www. nhtsa.gov/sites/nhtsa.gov/files/documents/traffic_safety_during_covid 19_01062021_0.pdf. Accessed 15 May 2021.

75. Woods-Fry H, Vanlaar WGM, Wicklund C, Robertson RD. Alcoholimpaired driving and COVID-19 in the United States results from the 2020 TIRF USA road safety monitor. 2020. Available at https://tirf.ca/. Accessed 27 May 2021.

76. Vanlaar BWGM, Woods-fry H, Lyon C, Robertson RD. Road safety monitor 2020: the impact of the COVID-19 pandemic on travel behaviour and road safety. 2020. Available at https://tirf.ca/downloading/?dlm$\mathrm{dp}-\mathrm{dl}=5478$. Accessed 27 May 2021

77. Avery AR, Tsang S, Seto EYW, Duncan GE. Stress, anxiety, and change in alcohol use during the COVID-19 pandemic: findings among adult twin pairs. Front Psychiatry. 2020;11:1-12.

78. Knell G, Robertson MC, Dooley EE, Burford K, Mendez KS. Health behavior changes during covid-19 pandemic and subsequent "stay-at-home" orders. Int J Environ Res Public Health. 2020;17:1-16.

79. Rodriguez LM, Litt DM, Stewart SH. Drinking to cope with the pandemic: the unique associations of COVID-19- related perceived threat and psychological distress to drinking behaviors in American men and women. Addict Behav. 2020:110:1-7.
80. Hobin E, Smith B. Is another public health crisis brewing beneath the COVID-19 pandemic? Can J Public Health. 2020;111:392-6.

81. Thomas FD, Berning A, Darrah J, Graham L, Blomberg R, Griggs C, et al. Drug and alcohol prevalence in seriously and fatally injured road users before and during the COVID-19 public health emergency. Natl Highw Traffic Saf Adm. 2020. Available at https://rosap.ntl.bts.gov/view/dot/ 50941. Accessed 28 May 2021.

82. Ramalho R. Alcohol consumption and alcohol-related problems during the COVID-19 pandemic: a narrative review. Australas Psychiatry. 2020;28:524-6.

83. Ward G.M. Vanlaar HW-F\& RDR. Road Safety Monitor 2020: Drinking and driving in Canada. 2020. Available at https://tirf.ca/downloading/?dlm$d p-d l=5753$. Accessed 27 May 2021.

84. Holmes EA, O'Connor RC, Perry VH, Tracey I, Wessely S, Arseneault L, et al. Multidisciplinary research priorities for the COVID-19 pandemic: a call for action for mental health science. Lancet Psychiatry. 2020;7:547-60.

85. Fiorillo A, Gorwood P. The consequences of the COVID-19 pandemic on mental health and implications for clinical practice. Eur Psychiatry. 2020;63:e32, 1-2.

86. Cao W, Fang Z, Hou G, Han M, Xu X, Dong J, et al. The psychological impact of the COVID-19 epidemic on college students in China. Psychiatry Res. 2020;287:112934.

87. Huang $Y$, Zhao N. Mental health burden for the public affected by the COVID-19 outbreak in China: who will be the high-risk group? Psychol Health Med. 2020;00:1-12.

88. Rajkumar RP. COVID-19 and mental health: a review of the existing literature. Asian J Psychiatry. 2020;52:102066.

89. Sheek-Hussein M, Abu-Zidan FM. Invited editorial: Covid-19 vaccine: hope and reality. Afr Health Sci. 2020;20:1507-9.

90. Mann RE, Asbridge M, Stoduto G, Smart RG, Goldbloom DS, Vingilis $E R$, et al. Psychological distress and collision involvement among adult drivers. Stress Health. 2010;26:127-34.

91. Beratis IN, Andronas N, Kontaxopoulou D, Fragkiadaki S, Pavlou D, Papatriantafyllou J, et al. Driving in mild cognitive impairment: the role of depressive symptoms. Traffic Injury Prev. 2017;18:470-6.

92. Clapp JD, Olsen SA, Danoff-burg S, Hagewood JH, Hickling J, Hwang VS, et al. Factors contributing to anxious driving behavior: the role of stress history and accident severity. Anxiety Disord. 2012;25:592-8.

93. Lemke MK, Apostolopoulos Y, Sönmez S. Syndemic frameworks to understand the effects of COVID-19 on commercial driver stress, health, and safety. J Transp Health. 2020;18:100877.

94. Hill N. Covid-19 may be a driver of poor behaviour on SA roads. 2020. Available at https://www.businesslive.co.za/bd/opinion/2020-12-09covid-19-may-be-a-driver-of-poor-behaviour-on-sa-roads/. Accessed 05 June 2021.

95. World Health Organization. Road traffic injury prevention training manual. Geneva: World Health Organization. 2006. Available at https:// www.who.int/publications/i/item/road-traffic-injury-prevention-train ing-manual. Accessed 10 Mar 2021.

96. Retallack AE, Ostendorf B. Current understanding of the effects of congestion on traffic accidents. Int J Environ Res Public Health. 2019:16:1-13.

97. Casado-Sanz N, Guirao B, Attard M. Analysis of the risk factors affecting the severity of traffic accidents on Spanish crosstown roads: the driver's perspective. Sustainability. 2020;12:2237.

98. Qureshi Al, Huang W, Khan S, Lobanova I, Siddiq F, Gomez CR, et al. Mandated societal lockdown and road traffic accidents. Accid Anal Prev. 2020;146:105747. https://doi.org/10.1016/j.aap.2020.105747.

99. Oguzoglu U. Discussion paper series: COVID-19 lockdowns and decline in traffic related deaths and injuries. IZA_Institute of Labor Economics. 2020. Available at http://ftp.iza.org/dp13278.pdf. Accessed 05 Mar 2021

100. Doucette ML, Tucker A, Auguste ME, Watkins A, Green C, Pereira FE, et al. Initial impact of COVID-19's stay-at-home order on motor vehicle traffic and crash patterns in Connecticut: an interrupted time series analysis. Injury Prev. 2021;27:3-9.

101. Toronto News. Ontario Provincial Police say traffic collisions down, but fatalities up in 2020. Toronto News. 2021. Available at https:// toronto.ctvnews.ca/ontario-provincial-police-say-traffic-collisionsdown-but-fatalities-up-in-2020-1.5349113. Accessed 23 May 2021. 
102. Abdullah A. Covid-19 impact in UAE : $84 \%$ decline in traffic accidents, zero deaths in Sharjah, UAE. Khaleej Times. 2020. Available at https:// www.khaleejtimes.com/coronavirus-pandemic/covid-19-impact-inuae-84-decline-in-traffic-accidents-zero-deaths-in-sharjah. Accessed 23 May 2021.

103. Dağ B. Traffic accidents reduced in Istanbul amid COVID-19. Anadolu Agency. 2020. Available at https://www.aa.com.tr/en/latest-on-coron avirus-outbreak/traffic-accidents-reduced-in-istanbul-amid-covid-19/ 1782717\#: :text=Accidents declined 34\% 25 in province, to prevent spread of virus\&text=Traffic accidents declined nearly 35 , to the provincial police. Accessed 15 Mar 2021.

104. Brodeur A, Cook N, Wright T. On the effects of COVID-19 safer-athome policies on social distancing, car crashes and pollution. IZA Discuss Pap. 2020;13255. Available at http://ftp.iza.org/dp13255.pdf. Accessed 15 Mar 2021.

105. Jefferies O, Kealey D, Yoong S, Houston R, Tennyson C. The effect of the Covid-19 pandemic on the workload of an adult major trauma centre in Northern Ireland. Ulster Med J. 2021;90:13-5.

106. Sun J, Li T, Li F, Chen F. Analysis of safety factors for urban expressways considering the effect of congestion in Shanghai, China. Accid Anal Prev. 2016;95:503-11.

107. Stoker S, McDaniel D, Crean T, Maddox J, Jawanda G, Krentz N, et al. Effect of shelter-in-place orders and the COVID-19 pandemic on orthopaedic trauma at a community level II trauma center. J Orthop Trauma. 2020;34:e336-42.

108. Rajput K, Sud A, Rees M, Rutka O. Epidemiology of trauma presentations to a major trauma centre in the North West of England during the COVID-19 level 4 lockdown. Eur J Trauma Emerg Surg. 2020. https://doi.org/10.1007/s00068-020-01507-w.

109. Department for Transport. Reported road casualties in Great Britain: provisional estimates year ending June 2020. 2021. Available at https://assets.publishing.service.gov.uk/government/uploads/ system/uploads/attachment_data/file/956524/road-casualties-yearending-june-2020.pdf. Accessed 05 June 2021.

110. National Highway Traffic Safety Administration (NHTSA). Early estimate of motor vehicle traffic fatalities in 2020. 2021. Available at https://crashstats.nhtsa.dot.gov/Api/Public/ViewPublication/813118. Accessed 05 June 2021

111. Nomura S, Kawashima T, Yoneoka D, Tanoue Y, Eguchi A, Gilmour $\mathrm{S}$, et al. Trends in deaths from road injuries during the COVID-19 pandemic in Japan, January to September 2020. Injury Epidemiol. 2020;7:1-7

112. Eid $\mathrm{HO}$, Abu-Zidan FM. Biomechanics of road traffic collision injuries: a clinician's perspective. Singap Med J. 2007;48:693-700.

113. Aleassa EM, Eid HO, Abu-Zidan FM. Effects of vehicle size on pedestrian injury pattern and severity: prospective study. World J Surg. 2013;37:136-40.

114. Eid HO, Barss P, Adam SH, Torab FC, Lunsjo K, Grivna M, et al. Factors affecting anatomical region of injury, severity, and mortality for road trauma in a high-income developing country: lessons for prevention. Injury. 2009;40:703-7.

115. Hefny AF, Barss P, Eid HO, Abu-Zidan FM. Motorcycle-related injuries in the United Arab Emirates. Accid Anal Prev. 2012:49:245-8.

116. Hefny AF, Eid HO, Abu-Zidan FM. Pedestrian injuries in the United Arab Emirates. Int J Injury Contr Saf Promot. 2015;22:203-8.

117. Transport Community Permanent Secretariat. Fatalities for 2020: annual statistics for Western Balkans Official. 2021. Available at https://www.transport-community.org/wp-content/uploads/2021/ 04/Annual-Statistics-2020.pdf. Accessed 25 May 2021.

118. Ministry of Health. $\mathrm{MOH}$ statistics and indicators: road traffic injuries and deaths. 2020. Available at https://www.moh.gov.sa/en/Ministry/ Statistics/Pages/Traffic-accidents.aspx. Accessed 27 May 2021.

119. National Police Agency. Overview: trends in numbers of traffic accidents and fatalities (1966-2020). Traffic bureau. 2020. Available at https://www.npa.go.jp/english/bureau/traffic/index.html. Accessed 05 June 2021.

120. Nippon.com. Japan's traffic accident deaths drop to record low in 2020. 2020. Available at https://www.nippon.com/en/japan-data/h00904/. Accessed 05 June 2021.
121. National Safety Council. National Safety Council preliminary semiannual estimates. 2021. Available at https://injuryfacts.nsc.org/motor-vehicle/ overview/preliminary-estimates/. Accessed 03 June 2021.

122. Waseem S, Nayar SK, Hull P, Carrothers A, Rawal J, Chou D, et al. The global burden of trauma during the COVID-19 pandemic: a scoping review. J Clin Orthop Trauma. 2021;12:200-7.

123. Lubbe RJ, Miller J, Roehr CA, Allenback G, Nelson KE, Bear J, et al. Effect of statewide social distancing and stay-at-home directives on orthopaedic trauma at a Southwestern level 1 trauma center during the COVID-19 pandemic. J Orthop Trauma. 2020;34:e343-8.

124. Jacob S, Mwagiru D, Thakur I, Moghadam A, Oh T, Hsu J. Impact of societal restrictions and lockdown on trauma admissions during the COVID-19 pandemic: a single-centre cross-sectional observational study. ANZ J Surg. 2020. https://doi.org/10.1111/ans.16307.

125. Nuñez JH, Sallent A, Lakhani K, Guerra-farfan E. Impact of the COVID-19 pandemic on an emergency traumatology service: experience at a Tertiary Trauma Centre in Spain. Injury. 2020;51:1414-8.

126. Zhu W, Li X, Wu Y, Xu C, Li L, Yang J, et al. Community quarantine strategy against coronavirus disease 2019 in Anhui: an evaluation based on trauma center patients. Int J Infect Dis. 2020;96:417-21.

127. Dhillon MS, Kumar D, Saini UC, Bhayana H, Gopinathan NR, Aggarwal S. Changing pattern of orthopaedic trauma admissions during COVID-19 pandemic: experience at a Tertiary Trauma Centre in India. Indian J Orthop. 2020. https://doi.org/10.1007/s43465-020-00241-0.

128. Ghafil C, Matsushima K, Ding L, Henry R, Inaba K. Trends in trauma admissions during the COVID-19 pandemic in Los Angeles County. California JAMA Netw Open. 2021;4:e211320.

129. Salottolo K, Caiafa R, Mueller J, Tanner A, Carrick MM, Lieser M, et al. Multicenter study of US trauma centers examining the effect of the COVID-19 pandemic on injury causes, diagnoses and procedures. Trauma Surg Acute Care Open. 2021;6:1-6.

130. Kamine TH, Rembisz A, Barron RJ, Baldwin C, Kromer M. Decrease in trauma admissions with COVID-19 pandemic. West J Emerg Med. 2020;21:819-22.

131. Fahy S, Moore J, Kelly M, Flannery O, Kenny P. Analysing the variation in volume and nature of trauma presentations during COVID-19 lockdown in Ireland. Bone Jt Open. 2020;1:261-6.

132. Christey G, Amey J, Campbell A, Smith A. Variation in volumes and characteristics of trauma patients admitted to a level one trauma centre during national level 4 lockdown for COVID-19 in New Zealand. N Z Med J. 2020;133:81-8.

133. Ajayi B, Trompeter A, Arnander M, Sedgwick P, Lui DF. 40 days and 40 nights: clinical characteristics of major trauma and orthopaedic injury comparing the incubation and lockdown phases of COVID-19 infection. Bone Jt Open. 2020;1:330-8.

134. BBC News. Emptier US roads more lethal in coronavirus pandemic, report says. 2020. Available at https://www.bbc.com/news/world-uscanada-52753925. Accessed 10 Mar 2021.

135. Department of Infrastructure, Transport, Regional Development and Communications/Bureau of Infrastructure and Transport Research Economics. Archived road deaths Australia-monthly bulletins: road deaths Australia: April 2020. 2021. Available at https://www.bitre.gov. au/sites/default/files/documents/rda_apr_2020.pdf. Accessed 15 May 2021.

136. Department of Infrastructure, Transport, Regional Development and Communications/ Bureau of Infrastructure and Transport Research Economics. Archived road deaths Australia-monthly bulletins. 2021: road deaths Australia December 2020. Available at https://www.bitre.gov.au/ sites/default/files/documents/rda_dec2020.pdf. Accessed 15 May 2021.

137. International Transport Forum. Canada road safety. 2020. Available at https://www.itf-oecd.org/sites/default/files/canada-road-safety.pdf. Accessed 15 Apr 2021.

138. World Health Organization. Using COVID-19 lockdown road-crash data to inform transport safety policy: Cali, Colombia. 2020. Available at https://cdn.who.int/media/docs/default-source/urban-health-docum ents/cali_pdf-version_final_14-may.pdf?sfvrsn=ee0bf487_9. Accessed 15 Apr 2021.

139. New Zealand Police. 2020 road deaths down on 2019: the number of deaths on New Zealand roads in 2020 was down on 2019, but it's still too many, says the National Road Policing Manager. 2021. Available at 
https://www.police.govt.nz/news/release/2020-road-deaths-down2019. Accessed 25 May 2021.

140. Jun-tae K. Seoul sees lowest traffic fatalities in 2020. The Korean Herald. 2020. Available at http://www.koreaherald.com/view.php?ud $=20210$ 207000192. Accessed 25 Apr 2021.

141. Maryada VR, Mulpur P, Guravareddy AV, Pedamallu SK, Vijay BB. Impact of COVID-19 pandemic on orthopaedic trauma volumes: a multicentre perspective from the State of Telangana. Indian J Orthop. 2020:54:368-73.

142. Navsaria PH, Nicol AJ, Parry CDH, Matzopoulos R, Maqungo S, Gaudin R. The effect of lockdown on intentional and nonintentional injury during the COVID-19 pandemic in Cape Town, South Africa: a preliminary report. S Afr Med J. 2020. https://doi.org/10.7196/SAMJ.2021.v111i2. 15318.

\section{Publisher's Note}

Springer Nature remains neutral with regard to jurisdictional claims in published maps and institutional affiliations.
Ready to submit your research? Choose BMC and benefit from:

- fast, convenient online submission

- thorough peer review by experienced researchers in your field

- rapid publication on acceptance

- support for research data, including large and complex data types

- gold Open Access which fosters wider collaboration and increased citations

- maximum visibility for your research: over $100 \mathrm{M}$ website views per year

At BMC, research is always in progress.

Learn more biomedcentral.com/submissions 